
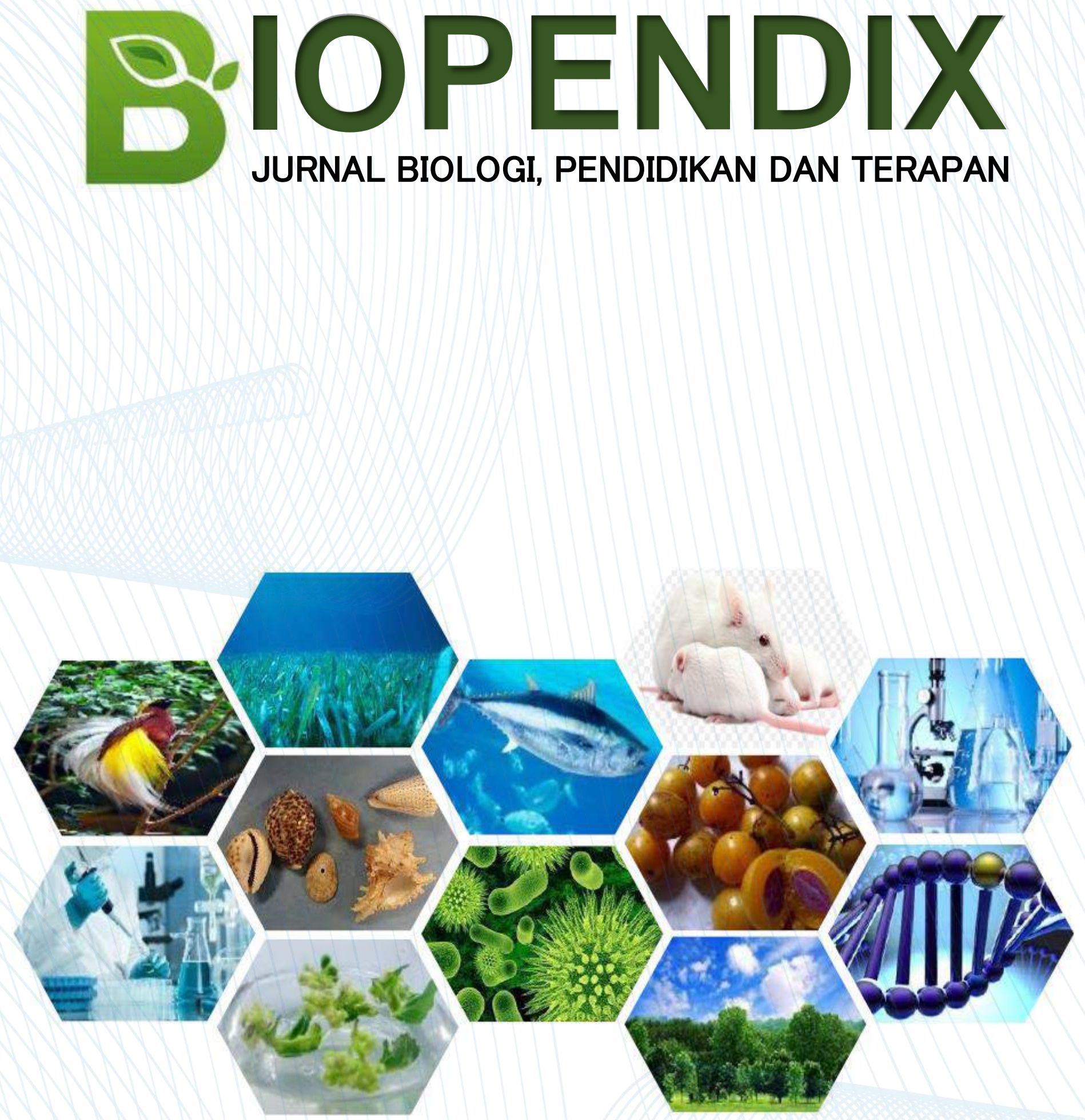

PUBLISHER BY:

BIOLOGY EDUCATION, UNPATTI AMBON - MALUKU 


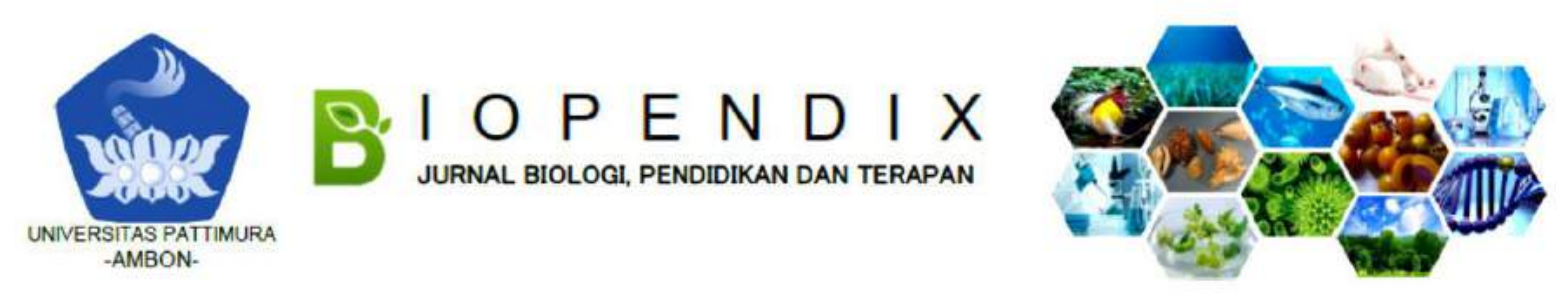

\title{
PENERAPAN METODE CERDAS (CERAMAH, DISKUSI, DANSIMULASI) DALAM MENINGKATKAN HASIL BELAJAR MATERI SISTEM PERNAPASAN PADA MANUSIA DI SMA NEGERI 5 AMBON KELAS XI
}

\author{
Nelci Dompeipen ${ }^{1}$, S. I. A. Salmanu*2, Ine Arini ${ }^{2}$ \\ ${ }^{1}$ Alumni Program Studi Pendidikan Biologi; ${ }^{2}$ Program Studi Pendidikan Biologi \\ *Corresponding author: S.IA. Salmanu; e-mail: siasalmanu.unpatti@gmail.com
}

\begin{abstract}
Background: Education is a process in order to influence students to be able to adapt to the environment so as to cause changes in themselves that are useful in people's lives. This study aims to obtain a picture of the activities of teachers in the learning process with lecture, discussion and simulation methods in improving learning outcomes of human respiratory system material in class $\mathrm{XI}$ MIA3 students of SMA Negeri 5 Ambon.

Method: This research is a Classroom Action Research conducted with 2 cycles, the stages of each cycle consisting of planning, implementation, observation and reflection. The subjects of this study were the teachers and all students of class XI MIA3 in SMA Negeri 5 Ambon in the 2019/2020 school year, totaling 34 students. The research instrument was in the form of observation sheets to obtain data on teacher activities in applying learning using lecture, discussion and simulation methods and questionnaire sheets were used to motivate students to learn biology data.

Results: The activity of the teacher with the method of learning lecture discussion and simulation in the first cycle obtained good and very good categories, and the second cycle became very good. In the first cycle the average learning outcomes of students' biology was 68.29 to 91.01 in the second cycle with very good category.

Conclusion: Learning outcomes in cycle II are better when compared to cycle I and in cycle II have experienced a significant increase in learning.
\end{abstract}

Keywords: Method, Lecture, Discussion, Simulation, Learning Outcomes, High School Biology

\begin{abstract}
Abstrak
Latar Belakang: Pendidikan adalah suatu proses dalam rangka mempengaruhi siswa agar dapat beradaptasi dengan lingkungan sehingga menimbulkan perubahan dalam diri yang bermanfaat dalam kehidupan masyarakat. Penelitian ini bertujuan untuk memperoleh gambaran aktivitas guru dalam proses pembelajaran dengan metode ceramah, diskusi dan simulasi dalam meningkatkan hasil belajar materi system pernapasan manusia siswa kelas XI MIA ${ }^{3}$ SMA Negeri 5 Ambon.

Metode: Penelitian ini merupakan PenelitianTindakan Kelas yang dilakukan dengan 2 siklus, tahapan dari masing-masing siklus terdiri atas perencanaan, pelaksanaan, observasi dan refleksi. Subjek penelitian ini adalah guru dan seluruh siswa kelas XI MIA ${ }^{3}$ SMA Negeri 5 Ambon tahun ajaran 2019/2020 yang berjumlah 34 orang siswa. Instrumen penelitian berupa lembar observasi untuk memperoleh data aktivitas guru dalam menerapkan pembelajaran dengan metode ceramah, diskusi serta simulasi dan lembar angket digunakan untuk data motivasi belajar biologi siswa.

Hasil: Aktivitas guru dengan metode pembelajaran ceramah diskusi dan simulasi di siklus I diperoleh kategori baik dan sangat baik, dan siklus II menjadi baik sekali.Pada siklus I rata - rata hasil belajar biologi siswa adalah 68,29 menjadi 91,01 pada siklus II dengan kategori baik sekali.

Kesimpulan: Hasil belajar pada siklus II lebih baik jika dibandingkan dengan siklus I dan pada siklus II menggalami peningkatan yang signifikan dalam belajar.
\end{abstract}

Kata Kunci: Metode, Ceramah, Diskusi, Simulasi, Hasil belajar, Biologi SMA 
Biopendix, Volume 6, Nomor 1, Oktober 2019, hlm. 46-52

\section{PENDAHULUAN}

Pendidikan adalah suatu proses dalam rangka mempengaruhi siswa agar dapat beradaptasi dengan lingkungan sehingga menimbulkan perubahan dalam yang bermanfaat dalam kehidupan masyarakat (Hamalik, 2001). Sebagaimana dijelaskan dalam Undang-undang sistem pendidikan nasional (Sisdiknas) pasal 1 ayat 1 No 20 Tahun 2003, disebutkan bahwa pendidikan adalah usaha sadar dan terencana untuk mewujudkan suasana belajar dan pembelajaran agar peserta didik secara aktif mengembangkan potensi dirinya untuk memiliki kekuatan spiritual keagamaan, pengendalian diri, kepribadian, kecerdasan, akhlak mulia, serta keterampilan yang diperlukan dirinya, masyarakat, bangsa dan Negara.

Hasil observasi yang dilakukan di kelas XI MIA ${ }^{3}$ SMA Negeri 5 Ambon pada pokok bahasan "Sistem Pernapasan Manusia" ditemukan bahwa hasil belajar siswa sudah sangat baik namun peneliti mencoba menambahkan metode simulasi dalam proses pembelajaran. Dengan adanya metode simulasi ini diharapkan siswa lebih lagi meningkatkan prestasi belajarnya. Karena dalam proses pembelajaran Guru lebih sering menggunakan metode ceramah dan diskusi, untuk itu peneliti mencoba memvariasikan antara metode ceramah, diskusi dan simulasi di SMA negeri 5 Ambon Kelas XI MIA ${ }^{3}$ pada materi Sistem Pernapasan Manusia, untuk lebih lagi meningkatkan hasil belajar siswa dari aspek kognitif, afektif dan psikomotorik.

Metode adalah cara yang paling tepat dan cepat dalam melakukan sesuatu. Kata tepat dan cepat inilah yang sering diungkapkan dengan efektif dan efisien (Ahmad, 2007). Metode ceramah adalah suatu cara mengajar dengan penyajian materi melalui penuturan dan penerangan lisan guru kepada siswa (Hamdani, 2011). Diskusi sebagai metode pembelajaran adalah proses pelibatan dua orang peserta atau lebih untuk berinteraksi saling bertukar pendapat (Gagne \& Briggs, 1979). Metode simulasi merupakan Proses pembelajaran yang objeknya cenderung bukan benda atau kegiatan yang sebenarnya, melainkan kegiatan mengajar yang sifatnya pura-pura (Anitah, 2008).

$\mathrm{Hal}$ ini menarik untuk dikaji karena merupakan suatu inovasi bagi guru untuk meningkatkan kreativitas dalam pembelajaran. Walaupun demikian, bukan berarti pembahasan ini tidak mendapat perhatian dari para peneliti. Paling tidak, terdapat beberapa peneliti dan penulis yang memberikan pengertian atau penjelasan tentang penerapan metode ceramah, diskusi dan simulasi untuk meningkatkan hasil belajar peserta didik. Petama, Amaliah (2014) dalam skripsinya yang berjudul "Penerapan Metode Ceramah dan Diskusi Dalam Meningkatkan Hasil Belajar PAI di SMA Negeri 44 Jakarta" menyatakan bahwa metode ceramah yang diterapkan dalam proses pembelajaran PAI oleh guru ialah metode ceramah yang diselingi dengan metode tanya jawab. Metode diskusi yang digunakan pada proses pembelajaran ialah metode diskusi kelompok kecil. Hasil belajar siswa dikelas yang menerapkan metode ceramah, dari segi kognitif mengalami kenaikan, dari segi afektif siswa dapat menerima pembelajaran dengan baik, dan dari segi psikomotorik siswa dapat terlibat cukup aktif secara psikomotrik. Hasil belajar siswa dikelas yang menerapkan metode diskusi, dari segi kognitif mengalami penurunan pada pertemuan ketiga, dari segi afektif siswa dapat menerima pembelajaran dengan cukup baik, dari segi psikomotorik siswa dapat terlibat aktif secara psikomotorik.

Kedua, Wahyuni dan Baroroh (2012) dalam jurnal yang berjudul "Penerapan Metode Pembelajaran Simulasi Untuk Meningkatkan Aktivitas Dan Prestasi Belajar Ekonomika Mikro" menyatakan bahwa berdasarkan analisis penelitian yang telah dilakukan, penerapan teknik simulasi terlaksana dengan baik. Penerapan metode pembelajaran simulasi dapat mengoptimalkan prestasi belajar siswa. Prestasi belajar siswa mengalami peningkatan dari prestasi belajar siklus I ke siklus II, dan dari siklus II ke siklus III.

Berdasarkan kajian literatur maupun informasi ilmiah yang telah ditelusuri, ternyata bahwa belum ada kajian atau penelitian yang khusus tentang pembelajaran menggunakan metode Ceramah, Diskusi dan Simulasi terhadap 
konsep Sistem Pernapasan Manusia yang dilakukan pada kelas $\mathrm{XI} \mathrm{MIA}^{3}$ di SMA Negeri 5 Ambon.

\section{METODE}

Penelitian ini menggunakan tipe penelitian deskriptif dengan metode Penelitian Tindakan Kelas (PTK). Penelitian ini dilaksanakan di SMA Negeri 5 Ambon pada tanggal 11 Maret 2019 - 11 April 2019. Subjek dalam penelitian ini adalah siswa SMA Negeri 5 Ambon kelas XI MIA $^{3}$ dengan jumlah populasi 34 siswa. Instrumen yang digunakan dalam penelitian ini adalah tes hasil belajar dalam bentuk pilihan ganda, lembar kerja siswa sebagai media pembelajaran yang digunakan untuk menilai aspek kognitif pengamatan sesuai instruksi guru dan lembar observasi. Pengumpulan data dalam penelitian ini diperoleh dengan teknik observasi, wawancara dan tes hasil belajar. Prosedur penelitian ini menggunakan rancangan pelaksanaan tindakan kelas yang terdiri dari 4 tahapan utama yaitu, perencanaan (Planning), pelaksanaan tindakan (Action), pengamatan (Observation) dan refleksi (Reflection). Teknik analisis data menggunakan analisis deskriptif.

\section{HASIL DAN PEMBAHASAN}

\section{a. Hasil}

\section{Hasil Tes Awal Pada Materi Pokok System Pernapasan Manusia}

Hasil tes awal menggambarkan kemampuan awal siswa tanpa adanya perlakuan apapun, terlihat bahwa hasil belajar beberapa siswa masih rendah. Hal ini bisa dilihat dari nilai tes awal yang dilakukan oleh guru pada awal kegiatan belajar mengajar (KBM) terlihat bahwa nilai tes awal sebelum dilakukan PTK atau nilai pra-siklus diketahui sebagian besar siswa memperoleh nilai dibawah KKM 65. Dengan demikian data hasil belajar siswa sebelum dilakukan tindakan penelitian dapat dilihat pada tabel 1.

\section{Tabel 1. Presentasi Hasil Tes Awal Pada Materi Pokok Sistem Pernapasan Manusia}

\begin{tabular}{cccc}
\hline Interval & Frekuensi & $(\%)$ & Kualifikasi \\
\hline $85-100$ & - & - & Baik sekali \\
$65-84$ & 17 & 50 & Baik \\
$55-64$ & 11 & 32,35 & Cukup \\
$35-54$ & 6 & 17,64 & Kurang \\
$0-34$ & - & - & Gagal \\
\hline Jumlah & 34 & 100 & - \\
\hline
\end{tabular}

Pada tabel diatas terlihat jelas bahwa dari 34 peserta didik yang menjadi subjek penelitian, peserta didik yang mempunyai pemahaman awal tentang materi pernapasan dengan kategori baik adalah sebanyak 17 orang dengan persentase $(50 \%)$. Siswa dengan kategori cukup adalah 11 orang dengan persentase (32,35\%), sedangkan siswa dengan kategori kurang adalah sebanyak 6 orang dengan persentase $(17,64 \%)$ dan siswa dengan kategori gagal sebanyak $0 \%$.

\section{Hasil Penelitian Pada Siklus I Materi Pokok Sistem Pernapasan Manusia}

\section{a. Perencanaan}

Dalam perencanaan pada siklus I ini peneliti menyusun perangkat pembelajaran berupa silabus dan RPP untuk siklus I yang sesuai dengan metode pembelajaran ceramah, diskusi dan simulasi, bahan ajar, dan format observasi peserta didik. Dalam perencanaan ini juga dibuat skenario pembelajaran yang sesuai dengan pembelajaran ceramah, diskusi dan simulasi. Skenario ini diharapkan mampu menarik perhatian siswa.

\section{b. Pelaksanaan tindakan}

Pelaksanaan tindakan dilaksanakan sesuai rencana pembelajaran yang telah disusun pada tahap perencanaan. Siklus I terdiri dari dua kali pertemuan dan diakhiri pertemuan kedua akan dilaksanakan tes akhir secara individu. Pembelajaran diawali dengan pemberian salam pada saat peneliti yang bertindak sebagai pengajar memasuki ruangan, kemudian pengajar mendata kehadiran peserta didik, selanjutnya pengajar memberikan penjelasan tentang materi yang akan dipelajari beserta tujuan pembelajaran yang akan dicapai. Untuk 
mengetahui hasil tes siswa pada siklus I dapat dilihat pada tabel 2 .

Tabel 2. Presentasi Hasil Tes Akhir Siklus I Pada Materi Pokok Sistem Pernapasan Manusia

\begin{tabular}{cccc}
\hline Interval & Frekuensi & $(\%)$ & Kualifikasi \\
\hline $85-100$ & - & - & Baik sekali \\
$65-84$ & 15 & 44,11 & Baik \\
$55-64$ & 18 & 52,94 & Cukup \\
$35-54$ & 1 & 2,94 & Kurang \\
$0-34$ & - & - & Gagal \\
\hline Jumlah & 34 & 100 & - \\
\hline
\end{tabular}

Dari tabel diatas menunjukkan bahwa dari 34 orang siswa kelas XI MIA ${ }^{3}$ SMA Negeri 5 Ambon yang menjadi subjek penelitian sesuai tes siklus I, 1 orang berada pada kategori kurang dengan persentase sebesar 2,94\%, 18 orang berada pada kategori cukup dengan persentase sebesar $52,94 \%$, dan 15 orang berada pada kategori baik dengan persentase sebesar $44,11 \%$. Disamping itu, sesuai dengan skor rata-rata hasil belajar siswa sebesar 68,29 jika dikonversi pada tabel distribusi frekuensi, maka berada pada kategori baik. Hal ini berarti bahwa rata-rata hasil belajar Biologi siswa kelas XI IPA MIA $^{3}$ SMA Negeri 5 Ambon berada pada kategori baik sehingga peneliti melanjutkan ke siklus II agar hasil belajar siswa lebih baik lagi.

\section{c. Pengamatan/observasi}

Berdasarkan hasil observasi pada tindakan pada pertemuan 1 dan 2, tampak suasana belajar yang diciptakan pengajar dan peserta didik selama proses penyampaian materi pembelajaran cukup baik dan sesuai dengan skenario pembelajaran yang telah disusun, hal ini tampak pada perhatian peserta didik yang tadinya belum mampu mengungkapkan ide maupun bertanya sudah ada yang mampu mengajukkan pertanyaan maupun gagasan serta dapat mendengarkan penyampaian materi dengan baik.

\section{d. Refleksi}

Refleksi pada siklus I dilakukan dengan mengkaji hasil dan permasalahan yang dihadapi. Pada siklus I diperoleh data bahwa siswa antusias dalam pembelajaran tersebut, walaupun belum optimal. Hal ini disebabkan siswa belum terbiasa menggunakan metode pembelajaran simulasi. Beberapa kelemahan yang ditemukan dalam siklus I adalah:

1) Posisi tempat duduk antar kelompok yang terlalu dekat yang memungkinkan siswa untuk saling menganggu antar kelompok. Selain itu posisi tempat duduk yang menyulitkan mobilitas peneliti untuk menilai aktivitas siswa.

2) Belum ada kesadaran dari dalam diri siswa untuk berani bertanya dan mengemukakan pendapat, peran Guru masih besar untuk memotivasi siswa agar mau bertanya, meskipun cara Guru dalam memotivasi siswa belum maksimal.

3) Tingkat aktivitas siswa saat diskusi kelompok berlangsung dan saat presentasi hasil simulasi masih kurang terutama terlihat pada saat presentasi.

4) Guru masih banyak berperan dalam diskusi dan presentasi hasil simulasi yang ditunjukkan dengan pertanyaanpertanyaan dari siswa yang ditanggapai oleh Guru.

5) Keterbatasan waktu sehingga menyebabkan Guru menyampaikan materi kurang maksimal dan pada tiap pertemuan pada siklus I hanya tiga kelompok yang dapat menyampaikan hasil Diskusi dan simulasinya dengan baik didepan kelas.

Berdasarkan hasil analisis dan refleksi siklus I yaitu, dengan melihat dari tingkat aktivitas siswa yang masih rendah pada lembar observasi dan hasil evaluasi yang dilakukan pada siklus I, dapat dilihat bahwa belum ada peningkatan hasil belajar biologi dengan menggunakan metode pembelajaran ceramah, diskusi dan simulasi karena kurangnya pemahaman terhadap materi dan penerapan metode ceramah, diskusi dan simulasi yang kurang baik dari guru dan peserta didik sehingga mengakibatkan 18 orang siswa berada pada kategori cukup dan 1 orang siswa berada pada kategori kurang, berdasarkan hasil yang diperoleh siswa jika dilihat berdasarkan KKM yang ditentukan yaitu, siswa harus mencapai nilai paling sedikit 65 baru dikatakan tuntas, sehingga aktivitas dan peran guru terhadap peserta didik 
tersebut belum nampak dengan baik sehingga dilakukan penyempurnaan pada siklus berikutnya.

\section{e. Hasil Penelitian Pada Siklus II Materi Pokok Sistem Pernapasan Manusia \\ 1) Perencanaan}

Berdasarkan hasil refleksi pada siklus I, maka yang menjadi alternatif pemecahan masalah guru memperbaiki hasil pada siklus kedua akan diterapkan. Selain itu, beberapa perencanaan yang akan dilaksanakan pada siklus II yaitu menyiapkan soal-soal tes akhir siklus II sebagai berikut:

1) Menyiapkan RRP sesuai dengan sintaks pembelajaran ceramah, diskusi dan simulasi.

2) Pada siklus II masih menggunakan format observasi yang telah disusun pada tahap perencanaan siklus I.

\section{2) Tindakan}

Prosedur pelaksanaan tindakan pada siklus II telah diterapkan dengan baik dan konsisten, yaitu mencakup semua unsur sesuai rencana pembelajaran yang telah disusun pada tahap perencanaan. Pada siklus II, pembelajaran dilaksanakan sebanyak 2 kali pertemuan. Pada akhir pertemuan kedua akan dilaksanakan tes akhir siklus secara individu.

Pelaksanaan kegiatan belajar mengajar pada tahap ini merupakan hasil revisi pada siklus sebelumnya dimana beberapa kekurangan tersebut akan diperbaiki pada siklus ini. Pengamatan (observasi) dilaksanakan bersamaan dengan kegiatan belajar mengajar. Selama proses belajar mengajar guru berusaha melaksanakan pembelajaran secara maksimal yang meliputi penerepan metode pembelajaran ceramah, diskusi, dan simulasi secara konsisten dengan mengulang materi sistem pernapasan manusia yang pernah diajarkan pada siklus I, mengatur posisi tempat duduk antar kelompok saling berjauhan agar mereka tidak saling menggangu dan juga memudahkan peneliti untuk mengontrol masing-masing kelompok, pemberian motivasi agar siswa lebih berperan aktif baik dalam presentasi maupun saat simulasi, dan pengaturan waktu serta usaha membangkitkan semangat belajar peserta didik sehingga kegiatan pembelajaran dilaksanakan sesuai dengan rencanarencana sebelumnya.

Pada tahap awal pembelajaran guru melakukan pemusatan perhatian siswa dengan melakukan apersepsi serta memberikan motivasi kepada peserta didik untuk mempersiapkan mereka secara fisik maupun psikis. Pada kegiatan inti guru meminta siswa untuk menemukan materi pelajaran secara mandiri, menyenangkan, relevan, melibatkan seluruh anggota kelompok. Kemudian guru membantu siswa untuk mengintregasi dan menyerap pengetahuan sesuai dengan metode pembelajaran ceramah, diskusi dan simulasi. Langkah selanjutnya yaitu, guru membantu siswa dalam menerapkan dan memperluas pengetahuan maupun ketrampilan dalam kegiatan belajar, agar hasil belajar dapat mengalami peningkatan dari siklus sebelumnya.

\section{Tabel 3. Hasil Tes Akhir Siklus II Pada Materi Pokok Sistem Pernapasa Manusia}

\begin{tabular}{cccc}
\hline Interval & Frekuensi & $(\%)$ & Kualifikasi \\
\hline $85-100$ & 29 & 85,3 & Baik sekali \\
$65-84$ & 5 & 14,7 & Baik \\
$55-64$ & - & - & Cukup \\
$35-54$ & - & - & Kurang \\
$0-34$ & - & - & Gagal \\
\hline Jumlah & 34 & 100 & - \\
\hline
\end{tabular}

Dari tabel diatas menunjukkan bahwa dari 34 orang siswa kelas $\mathrm{XI} \mathrm{MIA}^{3}$ SMA Negeri 5 Ambon yang menjadi subjek penelitian sesuai tes siklus I, 29 orang berada pada kategori baik sekali dengan persentase sebesar $85,3 \%$, dan 5 orang berada pada kategori baik dengan persentase sebesar $14,7 \%$. Disamping itu, sesuai dengan skor rata-rata hasil belajar siswa sebesar 91,01 jika dikonversi dengan tabel distribusi frekuensi, berada pada kategori baik sekali. Hal ini berarti bahwa rata-rata hasil belajar Biologi siswa kelas XI IPA MIA ${ }^{3}$ SMA Negeri 5 Ambon berada pada kategori baik sekali. Sehingga peneliti tidak melanjutkan ke siklus III.

\section{3) Pengamatan/Observasi}

Pengamatan dilaksanakan secara bersamaan ketika proses pembelajaran sedang berlangsung. Ketika proses 
pembelajaran berlangsung, yang melakukan pengamatan terhadap proses pembelajaran adalah guru senior SMA N 5 Ambon. Berdasarkatan pada hasil observasi yang dilakukan selama proses belajar mengajar pada siklus II, pelaksanaan kegiatan telah mengalami peningkatan dan telah memenuhi harapan dan rencana yang telah disusun pada siklus I. Hal ini dapat dilihat dari proses pelaksanaan pembelajaran kegiatan belajar mengajar yang secara keseluruhan telah maksimal dan tidak terdapat lagi kekurangan-kekurangan yang berarti, serta hasil evaluasi pada siklus ini telah memenuhi harapan dan rencana.

\section{4) Refleksi}

Hasil refleksi pelaksanaan siklus I merupakan gambaran tindakan yang akan dilaksanakan pada siklus II sebagai perbaikan dari tindakan yang telah dilakukan pada siklus I. Pada pertemuan pertama siklus II, peneliti melakukan sedikit perubahan yaitu, pada saat pembelajaran peneliti lebih fokus dalam penemuan dan permasalahan dan lebih memaksimalkan pemberian bimbingan pada penyelidikan dan penyelesaian masalah oleh siswa serta memberikan perhatian secara merata keseluruh siswa. Hal ini cukup memberikan hasil yang baik karena semakin banyak siswa yang memberikan jawaban masalah di akhir pembelajaran dan hampir semua siswa mampu menyelesaikan soal yang diberikan dengan baik dan juga mampu menjawab pertanyaan yang diberikan oleh guru. Pada pertemuan berikutnya hingga akhir siklus II terlihat bahwa proses pembelajaran melalui penerapan metode ceramah, diskusi dan simulasi memperlihatkan adanya peningkatan hasil belajar materi sistem pernapasan manusia siswa kelas XI SMA N 5 Ambon. Pada pertemuan terakhir, dilaksanakan tes siklus II. Mereka menunjukkan kesiapan dalam mengikuti tes dan lebih baik daripada tes siklus I. Berdasarkan pertimbangan terhadap hasil belajar yang diperoleh tersebut maka peneliti bersama guru mata pelajaran bersepakat untuk tidak melanjutkan ke siklus III.

\section{b. Pembahasan}

1. Siklus I

Pada nilai akhir siklus I siswa yang mendapat skor nilai dengan kategori baik sebanyak 25 siswa dengan persentase $(73,52 \%)$ dan siswa dengan kategori cukup adalah sebanyak 9 siswa dengan persentase $(26,48 \%)$. Disamping itu perolehan nilai rata-rata pada siklus I yaitu, 68,29 dan jika dikonversikan kedalam tabel distribusi frekuensi berada dalam kategori baik, sehingga peneliti melanjutkan ke siklus II agar hasil belajar siswa dapat lebih baik lagi. Pada siklus I dilakukan tahapan observasi dan refleksi. Observasi adalah kegiatan pengamatan yang dilakukan oleh pengamat (Arikunto, 2001). Pada tahap observasi, observer dalam hal ini peneliti mengumpulkan informasi, tentang proses pembelajaran. Berdasarkan hasil observasi hasil belajar siklus I menunjukkan bahwa, terlihat jelas dari 34 siswa yang menjadi subjek penelitian sesuai tes siklus I, yang dikategorikan tuntas berjumlah 15 siswa dengan persentase $44,11 \%$, dan yang dikategorikan tidak tuntas berjumlah 19 siswa dengan persentase 55,89\%. Berdasarkan hasil temuan pada tahap observasi siklus I ini, dikatakan bahwa ketuntasan hasil belajar individual belum maksimal karena belum mencapai ketuntasan belajar 65 sehingga peneliti melanjutkan ke siklus II.

\section{Siklus II}

Pada akhir siklus II, dapat dijelaskan bahwa siswa yang mendapatkan nilai dengan skor baik sekali adalah sebanyak 34 siswa dengan persentase (100\%) dengan hasil yang diperoleh pada siklus II menunjukkan hasil yang sangat memuaskan dari siklus sebelumnnya karena seluruh siswa dapat memperoleh nilai dengan kategori sangat baik dengan presentase (100\%).

Berdasarkan perolehan nilai akhir siswa pada siklus II menunjukkan bahwa 34 siswa yang menjadi subyek penelitian memperoleh nilai sangat baik dengan presentase sebanyak (100\%), 29 siswa berada pada kategori baik sekali dengan persentase sebesar $85,3 \%$, dan 5 siswa berada pada kategori baik dengan persentase sebesar $14,7 \%$. Disamping itu, sesuai dengan skor rata-rata hasil belajar 
siswa sebesar 91,01 jika dikonversi dengan tabel distribusi frekuensi, ternyata berada dalam kategori baik sekali. Siswa yang belum mencapai nilai ketuntasan semakin berkurang, dimana pada nilai akhir siklus I dengan menggunakan metode ceramah, diskusi dan simulasi materi sistem pernapasan manusia sebanyak $26,48 \%$ atau 9 siswa, sedangkan pada siklus II penerapan metode ceramah, diskusi dan simulasi materi sistem pernapasan manusia. Terdapat nilai dibawah KKM menjadi 0 siswa, dan siswa yang hasil belajarnnya tuntas atau mendapatkan nilai diatas KKM adalah 34 siswa dengan persentase $(100 \%)$.

\section{SIMPULAN}

Dapat disimpulkan bahwa hasil belajar pada siklus II lebih baik jika dibandingkan dengan siklus I dan pada siklus II menggalami peningkatan yang signifikan dalam belajar.

\section{DAFTAR PUSTAKA}

Amaliah, R.R., Fadhil, A., \& Narulita, S. 2014. Penerapan Metode Ceramah dan Diskusi Dalam Meningkatkan Hasil Belajar PAI di SMA Negeri 44 Jakarta. Jurnal IImu Pendidikan.
Anitah, S. 2008. Penelitian Tindakan Kelas. Jakarta: Bumi Aksara.

Ahmad, T. 2007. Metodologi Pengajaran Agama Islam. Bandung: PT Remaja Rosdakarya.

Arikunto, 2001. Penelitian Tindakan Kelas. Jakarta: Bumi Aksara.

Gagne, R.M., \& Briggs, L.J. 1979. Principle of Instructional Design. New Yorks: Holt Rinehart and Winston.

Hamalik, O. 2001. Proses Belajar Mengajar. Jakarta: Bumi Aksara.

Hamdani. 2011. Strategi Belajar Mengajar. Bandung: CV Pustaka Setia.

Undang- Undang Republik Indonesia Nomor 20 Tahun 2003 tentang Sistem Pendidikan Nasional. 8 Juli 2013. Jakarta: Lembaran Negara Republik Indonesia Tahun 2003 Nomor 4301, (online)

(http://sistempendidikannasional12.blog spot.in), diakses 20 oktober 2018.

Wahyuni, D., \& Baroroh, K. 2012. Penerapan Metode Pembelajaran Simulasi Untuk Meningkatkan Aktivitas Dan Prestasi Belajar Ekonomika Mikro. Jurnal Pendidikan, Vol. 9, No. 1, hal. 3. 